\title{
An Approach to Identify the Optimal Solutions in the Context of Energy and Cost Criteria for Buildings in Different Climates
}

\author{
Farklı Iklim Bölgelerindeki Binalarda Enerji ve Maliyet Kriterleri Bağlamında \\ Optimal Çözümlerin Belirlenmesine Yönelik Bir Yaklaşım
}

Aslıhan ŞENEL SOLMAZ

ABSTRACT

Buildings are the major energy consumers with a significant effect on energy efficiency improvements around the world. Ensuring energy efficiency in new and existing buildings is gaining momentum with recent initiatives that aim to increase social awareness. Today, there is a wide range of energy efficiency options from design solutions to energy efficient building materials, advanced HVAC systems, and renewable energy technologies. However the identification of optimal and/or most effective set of energy saving solutions within a large decision space for a specific building requires decision-support approaches. In this study, a simulation based multi-objective optimization approach based on the combination of EnergyPlus building performance simulation and GenOpt optimization program is employed to optimize building heating and cooling energy savings, and the cost criterion, Net Present Value (NPV) simultaneously while identifying the optimal set of energy saving solutions. The approach was applied to a hypothetical office building in different climate zones of Turkey (Izmir and Ankara) to demonstrate its applicability. Building envelope components on each façade were selected as decision variables, and an extensive solution space including alternative materials for the external walls, roof, ground floor insulation, different window types and shading system were generated for each decision variable. The results showed that the interaction between the conflicting objectives and the trade-offs should be explored while determining the most suitable building solutions with energy and cost effective manner.

Keywords: Building energy modeling; building energy performance; building performance optimization; building performance simulations; simulation based optimization.

Birincil enerji tüketicilerinden olan binalar dünya genelinde enerji etkin iyileştirmeler konusunda oldukça önemli bir etkiye sahiptir. Yeni ve mevcut binaların enerji etkinliğinin sağlanması, sosyal farkındalığı artırmayı amaçlayan son girişimlerle birlikte gittikçe ivme kazanmaktadır. Bugün binalar için, tasarım çözümlerinden enerji etkin yapı malzemelerine, ileri ısıtma-soğutma ve havalandırma sistemlerinden, yenilenebilir enerji teknolojilerine kadar çok sayıda ve çeşitlilikte enerji etkin uygulama seçeneği bulunmaktadır. Buna karşın, bu genişlikteki bir çözüm kümesi içerisinde, tanımlı bir bina için, optimal ve/veya en etkin enerji tasarruf çözümlerinin tanımlanabilmesi karar desteği sağlayacak yaklaşımları gerektirmektedir. Bu çalışmada, EnergyPlus bina performans simülasyonu ve GenOpt optimizasyon programının entegrasyonuna dayanan simülasyon tabanlı çok amaçı optimizasyon yaklaşımı, binanın ısıtma ve soğutma enerjisi tasarruflarını ve maliyet kriteri olan Net Bugünkü Değer (NBD)'i eş zamanlı optimize etmek ve optimal enerji tasarruf çözümlerini tanımlamak için kullanılmaktadır. Bu yaklaşım, Türkiye'nin farklı iklim bölgelerinde (İzmir ve Ankara) bulunan hipotetik bir ofis binasına uygulanarak pratikte uygulanabilirliğinin gösterilmesi amaçlanmıştır. Binanın her bir cephesindeki kabuk bileşenleri karar değişkenleri olarak seçilmiş ve her bir karar değişkeni için dış duvar, çatı, zemin döşemesi için alternatif yalıtım malzemelerini, farklı pencere türlerini ve gölgeleme sistemini içeren geniş çaplı bir çözüm kümesi geliştirilmiştir. Elde edilen sonuçlar, enerji ve maliyet etkin bir bakış açısıyla en uygun bina çözümlerinin belirlenmesi sürecinde çatışan amaç kriterler arasında meydana gelen etkileşimlerin ve ödünleşimlerin bilinmesi gerektiğini ortaya koymaktadır.

Anahtar sözcükler: Bina enerji modellemesi; bina enerji performansl; bina performans optimizasyonu; bina performans simülasyonları; simülasyon tabanlı optimizasyon.

Department of Architecture, Structure and Construction Design, Dokuz Eylül University Faculty of Architecture, İzmir, Turkey.

Article arrival date: May 23, 2016 - Accepted for publication: October 05, 2016

Correspondence: Aslıhan ŞENEL SOLMAZ. e-mail: asenelsolmaz@gmail.com

๑ 2016 Yıldız Teknik Üniversitesi Mimarlık Fakültesi - @ 2016 Yıldız Technical University, Faculty of Architecture 


\section{Introduction}

Building sector is one of the greatest energy consumers and releases substantial amounts of green house gases. For example, buildings are responsible for $40 \%$ of the world's total energy consumption ${ }^{1}$, with $41 \%$ of United States' total primary energy consumption and $40 \%$ of its $\mathrm{CO}_{2}$ emission $^{2}$, and $40 \%$ of European Union's total final energy consumption and $40 \%$ of its $\mathrm{CO}_{2}$ emissions ${ }^{3}$. As for Turkey, it is believed that the significant part (35\%) of the total energy consumption is from the building sector. As a consequence, buildings offer the greatest potential for reducing energy consumption and green house gas emissions in local and global scale. This particular problem directed EU and so many other countries to establish legislations and regulations in order to motivate energy efficiency in new and existing buildings. Energy Performance of Buildings Directive (EPBD) 2002/91/EC and its recast 2010/31/EU ${ }^{4}$ which is the main legislative instrument of EU was published for conservation of energy in buildings. In Turkey, the required arrangements including laws and regulations have been formed to comply with EPBD especially since 2007, with one of such attempts being BEP-TR, a national building energy performance calculation methodology. Consequently, improving building energy performance has a significant role not only to ensure the optimal energy use, both also to decrease the detrimental environmental impact of the buildings and the cost of energy.

Improving energy efficiency in buildings is a complex problem since buildings consist of numerous interrelated sub-systems (i.e. structural system and building materials, HVAC systems, building services) influencing the overall building performance. The building performance is determined as a consequence of concurrent interaction among parameters with their linear and nonlinear relationships. Besides the sub-systems of buildings, the energy loads of the buildings depend on the climatic conditions (air temperature, solar radiation etc.) as well as building surroundings (isolated building vs. surrounded by other buildings). For example, while the climate warming decreases the net-energy-load and winter heating loads in cool climates, shadowing may help decrease the summer cooling loads in warm climates. The decision makers from different disciplines such as architects and other design professionals have to be aware of such relationships and should consider climatic differences to prevent detrimental affects on the total energy use. Moreover, the decision makers should decide on the optimal decision from a multidimensional perspective by taking into account multiple performance criteria (energy, comfort, financial, environmental etc.). The problem actually turns into a multi-objective optimi-

\footnotetext{
1 Concerted Action EPBD, 2014.

2 US Department of Energy, 2012.
}

3 European Commission, 2015.

${ }^{4}$ European Union, 2010. zation problem that is characterized by the presence of multiple and conflicting criteria, and the optimal solution is a trade-off among them. For example, designers should not only focus on preventing the indoor overheating and decreasing the building cooling energy consumption during summer by selecting the suitable shading elements, but also on ensuring the maximum passive solar heating energy saving and decreasing the building heating energy consumption during winter. One-sided decisions to obtain energy savings may have an adverse affect on the total energy use. Another obstacle during decision making process is that there is a large decision space consisting of a broad range of energy efficiency solutions ranging from design solutions to using energy efficient building technologies, materials, and HVAC systems. Therefore, it is burdensome to identify the most feasible set of solutions within a large decision space to improve energy efficiency in a specific building. Such decisions cannot be made correctly without any decision support. To conclude, although a wide range of energy efficiency technologies is available, the decisionsupport approaches for guiding the decision-makers to identify the optimal and/or most suitable set of solutions is still a major methodological challenge.

Accordingly, in this study, the aim is to present an optimization based decision-support approach to define a set of energy saving solutions while maximizing building energy savings in a cost effective manner.

\section{Literature Review}

In the literature on building performance, the term "optimization" generally indicates the two different approaches aiming to seek the best solution among a variety of solution alternatives ${ }^{5}$.

In the first approach, the "optimization" term indicates an improvement process based on iteration of building performance simulations to reach sub-optimal solutions. In other words, this approach is based solely on generating a limited group of predefined alternative scenarios and evaluating each of these through building performance simulations on initially created thermal model to find the best scenario. Although, the building performance simulation tools (EnergyPlus, TRNSYS, ESP-r etc.) are widely used to investigate the effect of available alternative scenarios on building performance, the characteristic one at a time iteration of searching the best solution is naturally time consuming, and may only bring partial building performance improvement due to a search in a limited group of alternatives. For instance, Gucyeter and Gunaydin ${ }^{6}$ generated several alternative retrofit strategies using basic energy conservation measures for building envelope, evaluated each strategy, and optimized envelope retrofit strategies for an

\footnotetext{
Nguyen et. al., $2014 . \quad{ }^{6}$ Gucyeter and Gunaydin, 2012
} 
existing building through calibrated simulation model in order to minimize the building energy use and NPV. Similarly, Ganiç and Yılmaz ${ }^{7}$, generated different retrofit measures for thermal insulation, lighting, and chiller COP to find the best retrofit package per global cost and primary energy consumption criteria through a cost optimal method for an exemplary office building in different climates.

In the second approach, the process is named simulation-based optimization and the "optimization" term indicates an automated process that is generally based on the coupling between a building performance simulation and an optimization engine to find the optimal solution to a problem among a set of alternative solutions. Today, simulation based approaches play a key role finding optimal solution(s) to a problem, to identify a trade-offs among objectives, and to satisfy the multiple and conflicting objectives with much less time and effort compared to previous brute-force approach. When looking at the studies on simulation-based optimization, Chantrelle et. al. ${ }^{8}$, developed a tool named Multiopt that combines genetic algorithm (NSGA-II) with TRNSYS simulation program to select the best building envelope solution while optimizing building energy consumption, cost, thermal comfort and lifecycle environmental impact. Lin and Gerber $^{9}$ developed an MOO interface to achieve the coupling between Autodesk Revit and Green Building Studio energy analysis in order to support early design decision-making per optimum building usage intensity and design efficiency in a costly manner. Asadi et. al. ${ }^{10}$ proposed a multiobjective optimization model depending on the integration between genetic algorithm and artificial neural network (ANN) which are performed by coupling TRNSYS simulation program, GenOpt and Matlab in order to identify the most feasible building retrofit strategies while optimizing the energy consumption, retrofit cost and thermal comfort for an existing building. Senel Solmaz ${ }^{11,12}$ proposed a decision-support approach based on the integration of variance-based sensitivity analysis with multi-objective optimization in order to find primary and optimal set of energy saving solutions. Bayraktar ${ }^{13}$ developed a methodology to optimize building energy performance by using building design, HVAC and renewable system parameters while simultaneously considering building energy consumption, thermal comfort, environmental impact and cost criteria.

All these studies demonstrate the necessity of the simulation-based optimization approaches to identify the most feasible set of energy saving solutions per multiple criteria.

In this study, a simulation based optimization approach

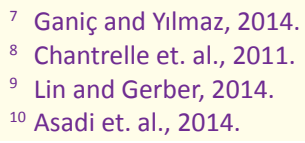

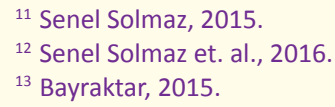

based on the combination of EnergyPlus building performance simulation with GenOpt optimization program is used for identifying the set of energy saving solutions while concurrently optimizing building energy savings and the cost criteria, Net Present Value (NPV) in a hypothetical office building in different climate zones of Turkey. Building envelope components on each façade are selected as decision variables, and optimal solutions were identified within a wide solution space generated with alternative insulation materials for the external walls, roof, and ground floor, and different window types and shading system.

\section{A Simulation-Based Optimization Approach}

The simulation-based optimization framework that integrates EnergyPlus 8.1.0 building performance simulation with GenOpt 3.1.0 generic optimization package is presented in Figure 1. As mentioned before, a multi-objective optimization problem is handled in this study and three objective criteria, building heating and cooling energy savings and a financial measure, NPV, are optimized simultaneously. GenOpt ${ }^{14}$ optimization program that aims to minimize the cost function evaluated by external simulation programs is selected due to its successful convergence to global optimum solutions and its ability to give close enough results to brute-force approach ${ }^{15}$. GenOpt can be integrated to building simulation programs that gives text file (.txt) as output. A validated and dynamic building performance simulation program EnergyPlus ${ }^{16}$ is selected for the building energy analyses.

According to Figure 1, GenOpt optimization program takes the EnergyPlus input file (template) with the extension of (.idf) that is prepared by the user, and by implementing each energy saving alternative also defined by the user, it can iteratively generate new idf files and run EnergyPlus to obtain new simulation results. There are five different input files (simulation input template, initialization file, command file, configuration file and fun.java file) shown on the figure are needed to be prepared by program users per handled problem (Figure 1). The content of each GenOpt input file is explained below:

1. Simulation input template (.idf): The core template file to be simulated.

2. Initialization file (optWin7.ini): Specification of input, output, log, and configuration files, weather file locations, and the objective function is also defined mathematically in this file.

3. Command file (command.txt): Definition of parameter names, initial values, minimum-maximum values in discrete form, optimization algorithm and optimization settings are made within this file.

\footnotetext{
${ }^{14}$ Wetter, 2011. $\quad{ }^{15}$ Hasan et. al., 2008. ${ }^{16}$ US Department of Energy, 2014.
} 


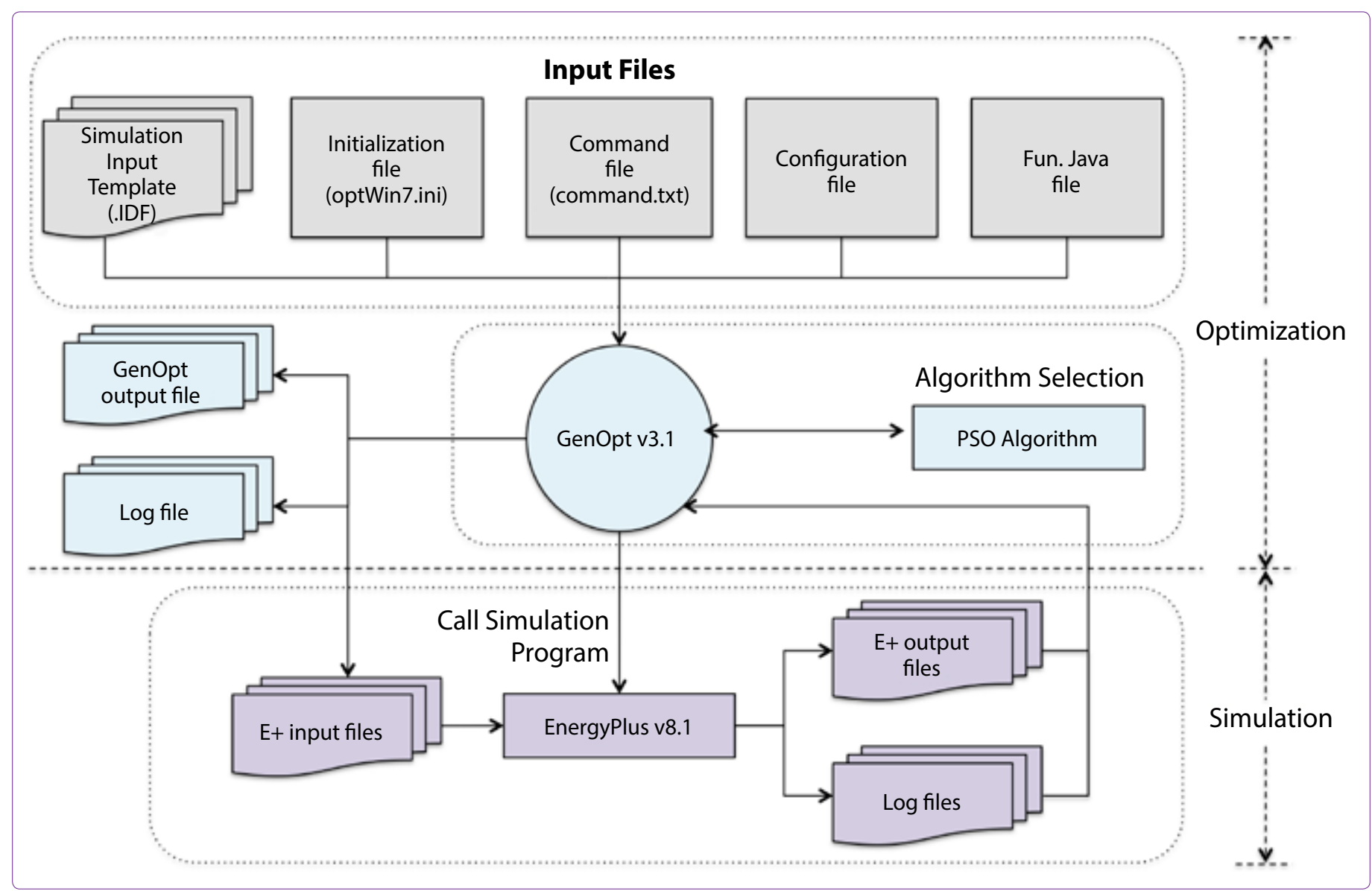

Figure 1. The integration between GenOpt optimization program and EnergyPlus building performance simulation adapted from. ${ }^{17}$

4. Configuration file: The start command instructions to call the EnergyPlus simulation program from inside GenOpt and error indicators.

5. Fun.Java file: The specification of solution alternatives, unit cost and NPV calculations.

In this framework, a building energy model is first created in Sketch-up Open Studio plug-in using EnergyPlus simulation engine and is saved as EnergyPlus input file (.idf). GenOpt is defined as the kernel in which many algorithms are integrated. In this study a population based meta-heuristic algorithm, Particle Swarm Optimization (PSO), is chosen for optimization algorithm because it is necessary to assign discrete values to input parameters in this study and it is suggested to use PSO in GenOpt for discrete values. PSO algorithm was first proposed for discrete parameter problems ${ }^{18}$. Similar to Genetic Algorithms, PSO algorithm consists of generations, and particles inside generations that imitate the swarm intelligence with social habits. Each particle is a potential solution and with each iteration, convergence to the generation with the optimal solution is achieved.

\footnotetext{
${ }^{17}$ Wetter, 2011.
}

\footnotetext{
${ }^{18}$ Eberhart and Kennedy, 1995.
}

The general steps for applying simulation based optimization method in this study are listed below:

1. Building energy modelling: This step includes the creation of a base-case building energy model with Sketch-up Open Studio and the conversion to EnergyPlus input file (.idf) for template.

2. Identification of decision variables and alternative energy saving solutions: This step includes the identification of the decision variables to be used in optimization process, and the creation of the solution space for optimization algorithm with alternative energy efficiency solutions for each variable and their related data (material thermo-physical properties, thickness, unit cost etc.)

3. Definition of an objective function: This step includes the definition of an objective function that guides the optimization algorithm with three objective criteria (heating energy saving, cooling energy saving and NPV) and the assignment of weights to each objective criterion.

4. Running the optimization program and getting optimal solutions per defined objective function. 


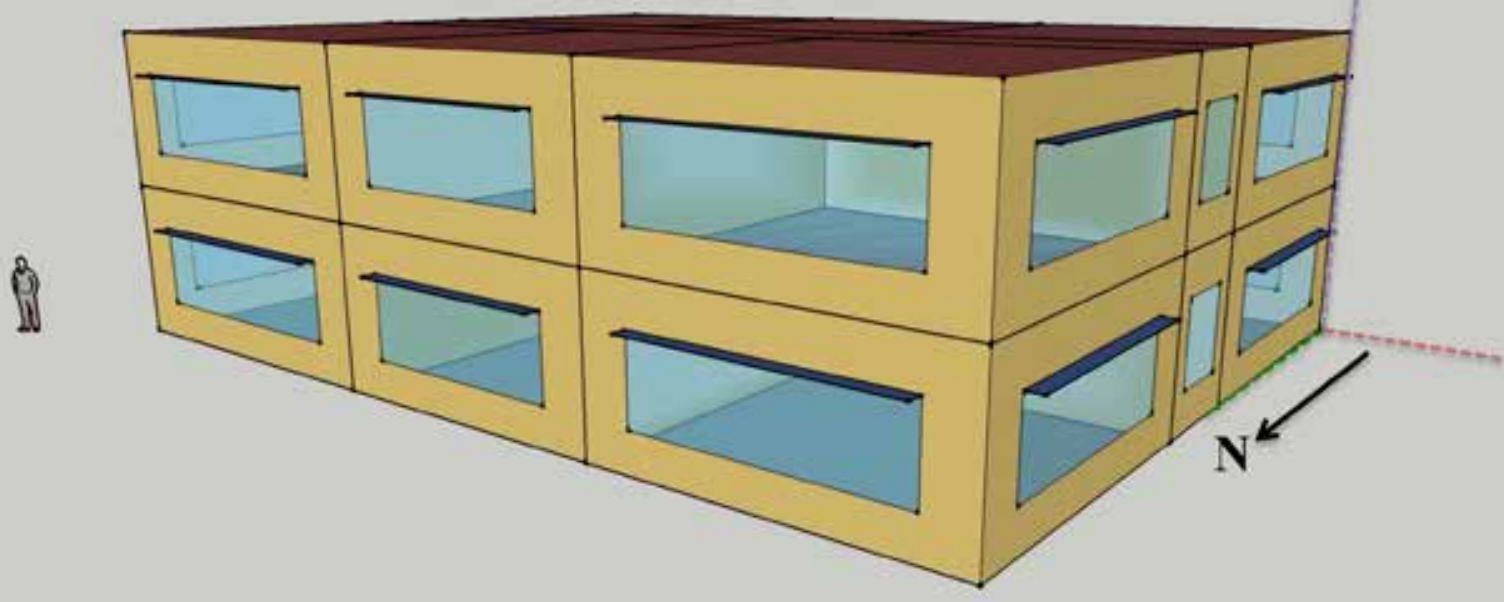

Figure 2. The hypothetical office building energy model created with Sketch-up Open Studio plug-in.

\section{Case Study}

The simulation based optimization approach is applied to a hypothetical office building in order to show its applicability for selecting optimal and satisfactory set of energy saving solutions separately in Izmir and Ankara that represent different climate zones in Turkey. Therefore, the minor aim of the study is to show how the optimal solutions are changed based on the climatic conditions.

In this study, it is assumed that the office building was constructed before the existing national standards and regulations in Turkey, and it needs improvement in energy performance with building retrofit.

\section{Building Energy Modelling}

The hypothetical office building is a two-floor building and oriented in north-south direction. The building has a rectangular plan scheme and all floors have the same plan configuration. General information of the building is given in Table 1. Each floor area is $268.75 \mathrm{~m}^{2}$ with $3.4 \mathrm{~m}$ floor height. Window-to-wall ratio of both south and north façades is $36 \%$ while it is $41 \%$ in east and west façades (Table 1 ).

The case building energy model was created with Sketch-up Open Studio plug-in ${ }^{19}$ (Figure 2) in accordance with thermo-physical properties of building elements, HVAC system properties, occupancy, and schedules. After getting the thermal model of the building, the model was exported as an IDF file for the input template.

The thermo-physical properties of the building envelope materials are presented in Table 2 . As mentioned before, it was assumed that the building was built before the recent standards in Turkey, so the building envelope or any other part of the building do not contain thermal insulation layer. According to Table 2 , the $U$ values of the exterior

\footnotetext{
${ }^{19}$ National Renewable Energy Laboratory (NREL), 2014.
}

Table 1. General information of the hypothetical office building

\begin{tabular}{lc}
\hline General Building Information & \\
\hline Building orientation & North-South \\
Number of floors & 2 \\
Floor height & $3.4 \mathrm{~m}$ \\
Total building height & $6.8 \mathrm{~m}$ \\
Total building floor and roof area & $268.75 \mathrm{~m}^{2}$ \\
Total exterior wall area (South-North) & $146.2 \mathrm{~m}^{2}$ \\
Total exterior wall area (East-West) & $104.5 \mathrm{~m}^{2}$ \\
Total window area (South-North) & $52.7 \mathrm{~m}^{2}$ \\
Total window area (East-West) & $42.5 \mathrm{~m}^{2}$ \\
Window to wall ratio (South-North) & $36 \%$ \\
Window to wall ratio (East-West) & $41 \%$ \\
Window to wall ratio of building & $38 \%$
\end{tabular}

wall, roof, ground floor and windows are $1.35 \mathrm{~W} / \mathrm{m}^{2} \mathrm{~K}, 2.74$ $\mathrm{W} / \mathrm{m}^{2} \mathrm{~K}, 2.17 \mathrm{~W} / \mathrm{m}^{2} \mathrm{~K}$ and $5.2 \mathrm{~W} / \mathrm{m}^{2} \mathrm{~K}$ respectively. All windows with PVC frames have single glazing with high SHGC value (0.87) and there is no shading component on any façade of the building as well. According to these values, the case building naturally does not meet the minimum requirements of TS-825.

There are seven thermal zones (six office spaces and one core circulation area) on each floor and the total thermal zones of the building are 14 . The building is occupied and heating-cooling systems are active between 09:00-18:00 on weekdays. The occupant density is 0.25 persons $/ \mathrm{m}^{2}$; the lighting power is $15.06 \mathrm{~W} / \mathrm{m}^{2}$ and the electric equipment power is $14.96 \mathrm{~W} / \mathrm{m}^{2}$ for each office thermal zone. The building heating and cooling systems were modelled as EnergyPlus Ideal Loads Air System and the thermostats 
Table 2. Thermo-physical characteristics of current materials of the base-case building envelope components

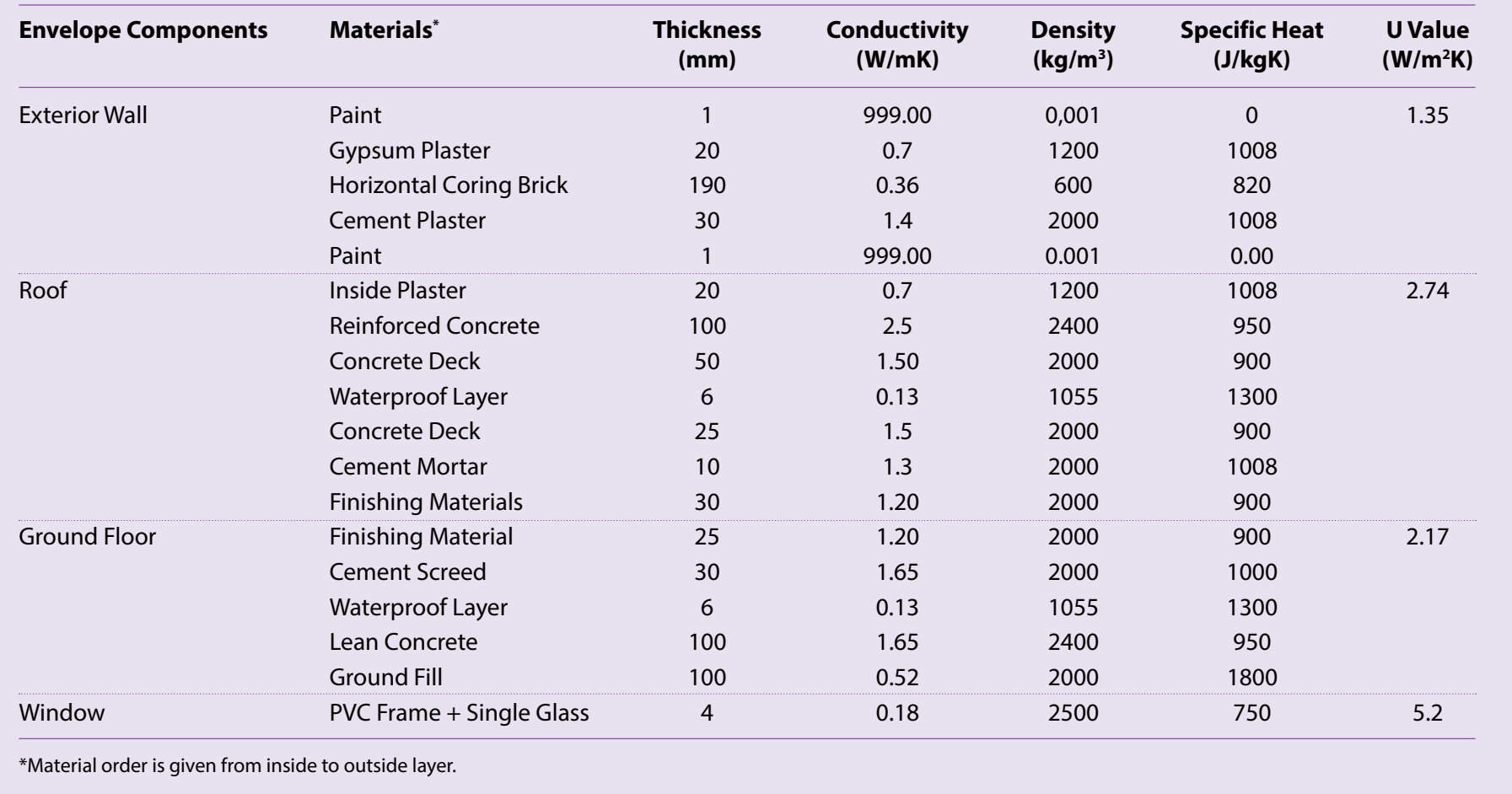

set points are $22^{\circ} \mathrm{C}$ and $26^{\circ} \mathrm{C}$ respectively. Infiltration rate per each zone is defined as $0.5 \mathrm{ACH}$ and each zone has the minimally required natural ventilation.

As mentioned before, it is imperative to develop optimal solutions for building energy performance in accordance with the different climatic conditions. Therefore, the effects of different climates on the solutions are performed for two exemplary cities, Izmir and Ankara. The base-case building was analysed in both cities that represent the hot-humid climate and temperate-dry climatic regions of Turkey respectively, and was expected to show significant differences for heating and cooling energy consumptions in order to show the effects of different climatic conditions on building energy analysis. Energy analysis of the case building was done using EnergyPlus. The annual heating and cooling energy consumptions of the building are calculated $30,100 \mathrm{kWh} /$ year and $38,581 \mathrm{kWh} /$ year in Izmir, and 82,000 kWh/year and 16,737 kWh/year in Ankara, respectively.

\section{Identification of Decision Variables and Alternative Energy Saving Solutions}

Identification of energy saving solutions reflects the total set of alternative actions in solution space for optimization. In this study, we focused on the building envelope that represents the most common applications for building energy efficiency and also refers to the existing standards in Turkey in order to generate energy efficiency measures. The passive energy efficiency strategies for five main building envelope components (exterior wall, roof, ground floor, window and shading system) were firstly defined as design variables in this study. In addition to this, each façade and each envelope component of the building was handled separately. For instance, the best insulation materials for exterior walls on south, north, east and west directions were determined separately. A total of 14 decision variables were derived from the five main envelope components during the optimization process. The decision variables handled in this study are listed below:

- The external wall insulation materials (south-northeast-west façades separately);

- The roof insulation materials;

- The ground floor insulation materials;

- The window type (south-north-east-west façades separately);

- The shading element (south-north-east-west façades separately).

The set of energy saving solutions in this study is a combination of material alternatives out of 14 decision variables.

Multiple alternative materials for each of five decision variables were generated to form the decision space. It was decided during this process that generated alternative materials for each of building envelope components 
should describe an existing material in the market. The list of generated alternative materials and their thermo-physical properties are presented on Tables 3-5. Each material was given an ID and the unit cost of each alternative was also identified to calculate the NPV criteria. According to Table 3, 10 XPS materials with the ID of A1 through A10, and 7 glass wool materials with the ID of B1 through B7 with different thickness were generated for the roof thermal insulation. Similarly, Table 3 includes 24 different exterior wall insulation materials, and 10 ground floor insulation materials. According to Tables 4 and 5, 18 alternative windows ranging from low-e single glazing to triple glazing

Table 3. Generated alternative insulation materials regarding roof, exterior wall and ground floor (Source: Senel Solmaz, 2015)

\begin{tabular}{|c|c|c|c|c|c|c|c|}
\hline $\begin{array}{l}\text { Envelope } \\
\text { Component }\end{array}$ & Material Name & ID & $\begin{array}{l}\text { Thickness } \\
(\mathrm{mm})\end{array}$ & $\begin{array}{l}\text { Conductivity } \\
\text { (W/mK) }\end{array}$ & $\begin{array}{c}\text { Specific } \\
\text { Heat }\end{array}$ & $\begin{array}{l}\text { Density } \\
\left(\mathbf{k g} / \mathrm{m}^{3}\right)\end{array}$ & $\begin{array}{c}\text { Cost } \\
\left(\mathrm{TL} / \mathrm{m}^{2}\right)\end{array}$ \\
\hline \multirow[t]{5}{*}{ ROOF (A-B) } & XPS Extruded & $\mathrm{A} 1-\mathrm{A} 10$ & $20-25-30-40-$ & 0.035 & 1500 & 30 & $4.64-25.60$ \\
\hline & Polystyrene & & $50-60-70-80-$ & & & & \\
\hline & Foam Board (A) & & $90-100$ & & & & \\
\hline & Glass Wool (B) & B1-B7 & 80-100-120- & 0.040 & 840 & 14 & $3.32-8.40$ \\
\hline & & & $\begin{array}{l}140-160-180- \\
200\end{array}$ & & & & \\
\hline \multirow{8}{*}{$\begin{array}{l}\text { EXTERIOR } \\
\text { WALL (E-F-G) }\end{array}$} & Rock Wool (E) & E 1-E7 & $30-40-50-60-$ & 0.037 & 840 & 150 & $6.15-24.53$ \\
\hline & & & $80-100-120$ & & & & \\
\hline & EPS Expanded & F1-F9 & $30-40-50-60-$ & 0.039 & 1500 & 16 & $2.65-12.25$ \\
\hline & Polystyrene & & 70-80-100- & & & & \\
\hline & Foam Boar (F) & & $120-140$ & & & & \\
\hline & XPS Extruded & G1-G8 & $30-40-50-60-$ & 0.035 & 1500 & 30 & $5.0-23.0$ \\
\hline & Polystyrene & & 70-80-100- & & & & \\
\hline & Foam Boar (G) & & 120 & & & & \\
\hline GROUND & XPS Extruded & $\mathrm{H} 1-\mathrm{H} 10$ & $20-25-30-40-$ & 0.035 & 1500 & 30 & $4.64-25.60$ \\
\hline \multirow[t]{2}{*}{ FLOOR (H) } & Polystyrene & & $50-60-70-80-$ & & & & \\
\hline & Foam Boar $(\mathrm{H})$ & & $90-100$ & & & & \\
\hline
\end{tabular}

Table 4. Generated energy efficiency solution alternatives regarding window types (Source: Senel Solmaz, 2015)

\begin{tabular}{|c|c|c|c|c|c|c|}
\hline $\begin{array}{l}\text { Envelope } \\
\text { Component }\end{array}$ & Material Name & ID & $\begin{array}{l}\text { U Value } \\
\left(W / m^{2} K\right)\end{array}$ & SHGC & $\begin{array}{l}\text { Vis. } \\
\text { Tran. }\end{array}$ & $\begin{array}{c}\text { Cost } \\
\left(\mathrm{TL} / \mathrm{m}^{2}\right)\end{array}$ \\
\hline WINDOW & Single Glazing, $4 \mathrm{~mm}$ & $\mathrm{C} 1$ & 5.2 & 0.87 & 0.9 & 23.5 \\
\hline \multirow[t]{17}{*}{ (C) } & Low-e single glazing, $4 \mathrm{~mm}$ & $\mathrm{C} 2$ & 4.2 & 0.65 & 0.79 & 26.5 \\
\hline & Tinted single glazing, $4 \mathrm{~mm}$ & $\mathrm{C} 3$ & 5.2 & 0.54 & 0.71 & 25.5 \\
\hline & Tinted low-e single glazing, $4 \mathrm{~mm}$ & C4 & 4.2 & 0.54 & 0.71 & 28.0 \\
\hline & Clear double glazing, air-filled, $4-12-4 \mathrm{~mm}$ & $\mathrm{C} 5$ & 2.9 & 0.75 & 0.8 & 36.0 \\
\hline & Clear double glazing, air-filled, 4-16-4mm & C6 & 2.7 & 0.75 & 0.8 & 36.5 \\
\hline & Clear double glazing, argon-filled, 4-12-4mm & C7 & 2.7 & 0.75 & 0.8 & 37.5 \\
\hline & Clear double glazing, argon-filled, 4-16-4mm & $\mathrm{C} 8$ & 2.6 & 0.75 & 0.8 & 38.0 \\
\hline & Low-e double glazing, air-filled, 4-12-4mm & $\mathrm{C} 9$ & 1.6 & 0.56 & 0.79 & 38.0 \\
\hline & Low-e double glazing, air-filled, 4-16-4mm & $\mathrm{C} 10$ & 1.3 & 0.56 & 0.79 & 38.5 \\
\hline & Low-e double glazing, argon-filled, 4-12-4mm & $\mathrm{C} 11$ & 1.3 & 0.56 & 0.79 & 39.5 \\
\hline & Low-e double glazing, argon-filled, 4-16-4mm & $\mathrm{C} 12$ & 1.1 & 0.56 & 0.79 & 40.0 \\
\hline & Tinted low-e double glazing, air-filled, $4-12-4 \mathrm{~mm}$ & $\mathrm{C} 13$ & 1.6 & 0.44 & 0.71 & 40.0 \\
\hline & Tinted low-e double glazing, air-filled, 4-16-4mm & $\mathrm{C} 14$ & 1.3 & 0.44 & 0.71 & 40.5 \\
\hline & Tinted low-e double glazing, argonfilled, $4-12-4 \mathrm{~mm}$ & $\mathrm{C} 15$ & 1.3 & 0.44 & 0.71 & 41.5 \\
\hline & Tinted low-e double glazing, argonfilled, $4-16-4 \mathrm{~mm}$ & $\mathrm{C} 16$ & 1.1 & 0.44 & 0.71 & 42.0 \\
\hline & Clear triple glazing, air-filled, 4-12-4-12-4mm & $\mathrm{C} 17$ & 1.1 & 0.73 & 0.78 & 43.0 \\
\hline & Clear triple glazing, air-filled, $4-16-4-16-4 \mathrm{~mm}$ & $\mathrm{C} 18$ & 1 & 0.73 & 0.78 & 44.0 \\
\hline
\end{tabular}


Table 5. Generated energy efficiency solution alternatives regarding shading materials of windows (Source: Senel Solmaz, 2015)

Envelope Component

SHADING (D)
Material Name

Horizontal fixed overhang
ID

D1-D9
Depth (m)

$0.2-0.3-0.4-0.5-0.6-0.7-0.8-0.9-0$
Cost $\left(\mathrm{TL} / \mathrm{m}^{2}\right)$

30 with different thermo-physical properties (with the ID of C1 through C18) were selected, and 9 alternative shadings with different depths (with the ID of D1 through D9) were selected for the shading system.

Considering the total number of alternatives, the optimization algorithm does the search within a massive solution space to get to the optimal solutions.

\section{Definition of An Objective Function}

After creating the building energy model ( $1^{\text {st }}$ step) and generating the solution space for optimization by identifying the alternative energy saving solutions ( $2^{\text {nd }}$ step), the third step is to define an objective function in order to guide the optimization process. As mentioned before, a multi-objective optimization problem is used in this study with three objective criteria, heating energy saving, cooling energy saving and NPV that were optimized simultaneously. GenOpt, which is one of the mostly used tools in building optimization, has only one cost function that is minimized during optimization process. Therefore, a "weighted-sum" approach was used to integrate these three objectives into GenOpt. According to the weighted sum approach, different weight factors are assigned to each criterion, and the objective function is simply the weighted sum of the criteria ${ }^{20}$. The objective function with three objectives is shown in Eq. 1,

$$
f(x)=a \cdot f_{1}(x)+b \cdot f_{2}(x)+c \cdot f_{3}(x)
$$

where, $f_{1}(x)$ is the percentage of annual heating energy saving, $f_{2}(x)$ is the percentage of annual cooling energy saving per base-case values, and $f_{3}(x)$ is the percentage of NPV saving, respectively. In Eq. 1, a, b and c are the weight factors or weight coefficients of each criterion. Each objective's formula is entered into the relevant GenOpt input file.

Building annual heating and cooling savings are calculated in accordance with Eq. 2 and Eq. 3 respectively,

$$
\begin{aligned}
& f_{1}(x)=\left(B H C-B H C_{b c}\right) / B H C_{b c} \times 100 \\
& f_{2}(x)=\left(B C C-B C C_{b c}\right) / B C C_{b c} \times 100
\end{aligned}
$$

where, $B H C$ is the recent value of building heating consumption and $B H C_{b c}$ is the base-case heating energy consumption value. Similarly, per Eq. 3, BCC defines the recent value of building cooling energy consumption, and $B C C_{b c}$ defines base-case cooling energy consumption value.

\footnotetext{
${ }^{20}$ Wright et. al., 2002.
}

Heating and cooling energy consumption data were collected from EnergyPlus.

NPV is the economical indicator for the feasibility of the project, and it is widely used in building optimization research. NPV is calculated according to Eq. 4:

$$
\mathrm{NPV}=\sum_{t=1}^{N} \frac{R_{t}}{(1+i)^{t}}-\text { Inilnv }
$$

In Eq. $4, i$ is the nominal discount rate, $t$ is the duration of the cash flow, $R_{t}$ is the net cash flow at time $t$ including inflation rate for the energy prices hikes. The NPV was calculated for 10 years with $4.5 \%$ nominal discount rate and $10 \%$ inflation rate. Owing to calculating the first two objectives (heating and cooling savings) as percentages, NPV is also calculated as percentage in the objective function. Therefore, the third objective criterion $f_{3}(x)$ that includes initial investment (Inilnv) and NPV is given in Eq. 5.

$$
f_{3}(x)=(N P V+\operatorname{lnilnv}) / \operatorname{lnilnv} \times 100
$$

After setting the objective function within the GenOpt with three objectives, the most important step at this point is to assign suitable weight factors to each objective criterion based on the aim of the project because the optimization will progress per these assigned weights.

In this study, the main aim is to find both optimal and satisfactory set of energy saving solutions in Izmir and Ankara having different climatic conditions. Therefore, two different optimization runs (Optimization I and II) were done for both Izmir and Ankara separately. The first optimization run was done to obtain maximum heating energy saving result while the second optimization run was for maximum cooling energy saving. Thus, it was done by increasing the weight factor of the criterion to focus on while decreasing the others in each optimization. The assigned weights for each criterion on different optimization runs are given below:

- Optimization I: Optimization to obtain maximum heating energy saving: $a=20 ; b=1 ; c=-0.05$

- Optimization II: Optimization to obtain maximum cooling energy saving: $a=1 ; b=10 ; c=-0.1$

As mentioned before, $a, b$ and $c$ are the weight coefficients of heating energy saving, cooling energy saving and NPV criteria respectively. In order to get an optimal solution for maximum heating energy saving, the coefficient 
of heating saving (a) was given 20 , while smaller values were assigned to the other factors. Similarly, in order to obtain maximum cooling energy saving, the assigned value to weight factor of cooling saving (b) is much bigger than the other weight values. These weights were decided as a result of some trial optimization runs where the algorithm was made sure not to converge to a local optimum.

\section{Optimization Results and Discussion}

During GenOpt optimization run, the optimization algorithm made a search within a very large solution space of $\sim 10^{11}$ alternative solutions, and convergence was achieved at about $18-20^{\text {th }}$ generation along the run. The number of generations was limited to 40 and a population size was chosen as 40 . The each simulation run took $\sim 22 \mathrm{sec}$ using the parallel computation feature of EnergyPlus. The total optimization time was around $\sim 3.5$ hours for each run in Izmir and Ankara, using a computer with Intel i7 QuadCore CPU $2.4 \mathrm{GHz}, 8 \mathrm{~GB}$ RAM.

Optimal Set of Solutions based on Heating and Cooling Energy Savings for Izmir

The results of Optimization I and Optimization II, which are for obtaining maximum heating and cooling energy savings respectively, are presented in Figure $3 a, b$.

On Figure $3 a, b$, the individual objectives are plotted against each other with 10-year NPV calculations on $y$ axis, the cooling energy savings on $\mathrm{x}$-axis and the heating energy savings on z-axis with colorbar. Each data point on Figure $3 a, b$ represents a set of energy saving solutions and they are a combination of alternative energy saving solutions assigned to 14 defined decision variables. According

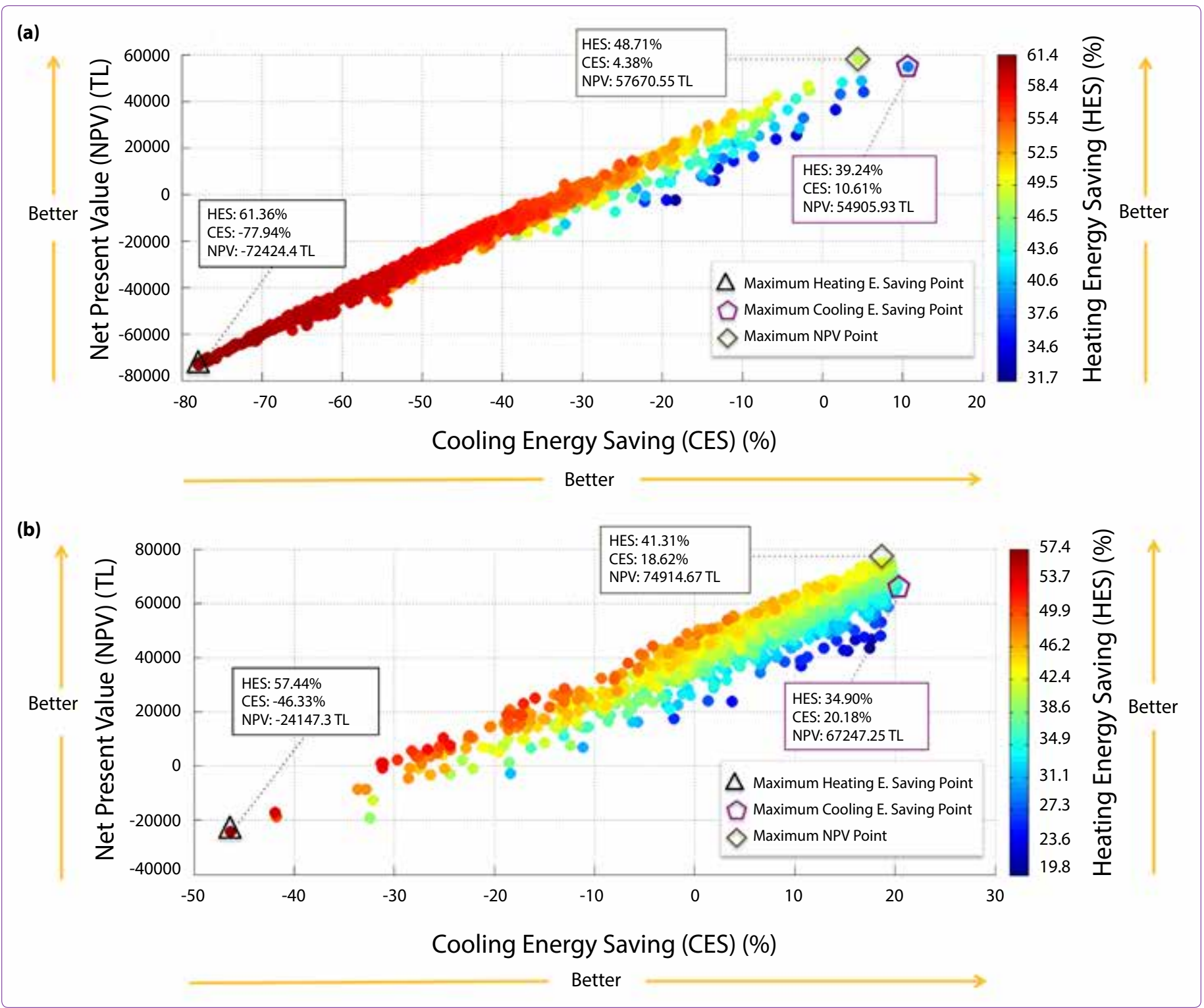

Figure 3. Optimization results for Izmir (a) the results for maximum heating energy saving, (b) the results for maximum cooling energy saving. 
to Figure $3 a, b$, there are positive and negative correlations among objective criteria. For example, while the cooling energy savings are negatively correlated with the heating energy savings, they are positively correlated with NPV. Similarly, the heating energy savings are negatively correlated with both NPV and the cooling energy savings; there are clear trade-off relationships among objective criteria. Thus, the solution alternatives to obtain more heating energy savings reduce both the NPV and the cooling energy savings. On the contrary, the set of solutions to obtain more cooling savings positively affect the NPV. Three separate data points marked on both Figure $3 a$ and $b$ represent the maximum heating energy saving point (triangle), the maximum cooling energy saving point (diamond), the maximum NPV point (pentagon) with the values obtained. The maximum NPV points on both Figures $3 a$ and $b$ are near the maximum cooling energy saving points while they are far away from the maximum heating energy saving points.

On Figure 3a, compared to the base-case condition, the maximum heating energy saving is $61.36 \%$ with $77.94 \%$ in cooling energy loss and 72424.4 TL NPV loss at the end of the 10-year period. On the same figure, the maximum cooling saving is $10.61 \%$ corresponding to $39.24 \%$ heating energy saving and 54905.93 TL NPV gain. On the maximum NPV point on Figure $3 a$, at the end of the 10 -year, NPV is positive, and the gain is $57670.55 \mathrm{TL}$, while the heating energy saving is $48.71 \%$ and the cooling energy saving is $4.38 \%$.

On Figure $3 \mathrm{~b}$, compared to the base-case condition, the maximum cooling energy saving is $34.90 \%$ corresponding to $20.18 \%$ heating energy saving, and 67247.25 TL NPV gain at the end of the 10 -year period. The maximum heating energy saving is $57.44 \%$ with $46.33 \%$ in cooling energy loss, and 24147.3 TL NPV loss. On the maximum NPV point on Figure $3 b, 10$-year NPV gain is $74914.67 \mathrm{TL}$, while the heating energy saving is $41.31 \%$ and the cooling energy saving is $18.62 \%$.

As seen from the results, NPV can attain a positive or negative value at the end of the declared period. If NPV is negative, the initial investment cannot be covered at the end of the calculation period. Yet, the initial investment is met and the project starts to save money due to energy savings if NPV is positive.

In one of the chosen solutions on Figure $3 a, b$ for obtaining the maximum heating energy savings, there are losses in both cooling and NPV. On the other hand, at the maximum cooling saving and NPV points, there are gains in all of the three objectives simultaneously. Although the first optimization was done to obtain the maximum heating energy savings, we cannot conclude that this point is the most satisfactory compromise due to losses in other objectives. The maximum cooling energy saving point on
Figure $3 a$ is not the optimal solution based on the assigned weights to objectives, and yet we can propose this solution as one of the satisfactory set of solutions within this study due to having more balanced savings among all the objectives.

As mentioned before, each data point on Figure $3 a, b$ has a set of alternative energy saving solutions. The combination of assigned alternative energy saving solutions of each data point marked on both Figure $3 a, b$ are presented with their IDs in Table 6 under the title of "Optimization I (For maximum heating energy saving)" and "Optimization II (For maximum cooling energy saving)" separately.

According to Table 6's results for Optimization I, at the maximum heating saving point, window alternative with the ID of C18 triple glazing (see Table 4) which have lowest $U$ value $(1 \mathrm{~W} / \mathrm{m} 2 \mathrm{~K})$ and high SHGC value $(0.73)$ was assigned to all windows of entire building in order to decrease building heating energy consumption. Meanwhile, the shading elements were not designated to any windows (with the ID of D9) (see Table 5). While the alternative insulation material B7 with the highest thickness $(200 \mathrm{~mm})$ was selected for roof insulation, the alternative material with the ID of $\mathrm{H} 10$ having the highest thickness was assigned to ground floor in order to increase heating energy savings (see Table 3). As for the exterior wall, the XPS insulation material with the ID of G8 which has the lowest conductivity $(0.035 \mathrm{~W} / \mathrm{mK})$ and the highest thickness within the group was assigned to windows in north, east and west directions. Additionally, the EPS insulation material (ID of F9) with the $0.039 \mathrm{~W} / \mathrm{mK}$ conductivity value and $140 \mathrm{~mm}$ thickness was assigned to wall in the south direction. It is a fair interpretation that this set of solutions is rational to obtain maximum heating energy savings. According to the result of maximum cooling energy saving point as part of Optimization I (Table 6), different alternative windows were assigned to windows in different directions. For example, while the window alternative "tinted low-e double glazingair filled" with the ID of $\mathrm{C} 13$ (with $U$ value $=1.6 \mathrm{~W} / \mathrm{m}^{2} \mathrm{~K}$ and SHGC value $=0.44$ ) was assigned to south windows, window alternative (ID of C8) with higher $U$ value $\left(2.6 \mathrm{~W} / \mathrm{m}^{2} \mathrm{~K}\right)$ and SHGC (0.75) was selected for north façade windows (see Table 4). The window alternatives with the ID of C4 and C12 were assigned to windows on east and west directions, respectively. The alternative shading with the ID of D8 having the highest depth value $(0.9 \mathrm{~m})$ (see Table 5 ) was selected for all windows in each direction. While the alternative insulation material with the ID of B7 was assigned to roof as in the maximum heating saving point, the alternative insulation material with almost the lowest thickness (ID of H2) was selected for ground floor unlike the maximum heating saving point. This result may arise due to the adverse effect of ground floor insulation on cooling energy saving in 
Table 6. The results of Optimization I and II for Izmir: The combination of assigned alternative energy saving solutions (with their IDs) of each data point marked on both Figure 3a-3b

\begin{tabular}{|c|c|c|c|c|c|c|}
\hline \multirow{3}{*}{$\begin{array}{l}\text { Izmir } \\
\text { Building Envelope } \\
\text { Components } \\
\text { (Decision Variables) }\end{array}$} & \multicolumn{3}{|c|}{$\begin{array}{l}\text { Optimization I } \\
\text { (For Maximum Heating Energy Saving) }\end{array}$} & \multicolumn{3}{|c|}{$\begin{array}{c}\text { Optimization II } \\
\text { (For Maximum Cooling Energy Saving) }\end{array}$} \\
\hline & \multicolumn{3}{|c|}{ The ID of Alternative Energy Saving Solutions ${ }^{*}$} & \multicolumn{3}{|c|}{ The ID of Alternative Energy Saving Solutions ${ }^{*}$} \\
\hline & $\begin{array}{c}\text { Max. } \\
\text { Heating } \\
\text { Saving Point }\end{array}$ & $\begin{array}{c}\text { Max. } \\
\text { Cooling } \\
\text { Saving Point }\end{array}$ & $\begin{array}{c}\text { Max. } \\
\text { NPV Point }\end{array}$ & $\begin{array}{c}\text { Max. } \\
\text { Heating } \\
\text { Saving Point }\end{array}$ & $\begin{array}{c}\text { Max. } \\
\text { Cooling } \\
\text { Saving Point }\end{array}$ & $\begin{array}{l}\text { Max. } \\
\text { NPV Point }\end{array}$ \\
\hline Window-South & C18 & $\mathrm{C} 13$ & C13 & $\mathrm{C} 18$ & $\mathrm{C} 13$ & $\mathrm{C} 13$ \\
\hline Window-North & C18 & $\mathrm{C} 8$ & $\mathrm{C} 16$ & $\mathrm{C} 18$ & C3 & $\mathrm{C} 14$ \\
\hline Window-East & $\mathrm{C} 18$ & $\mathrm{C} 4$ & $\mathrm{C} 18$ & $\mathrm{C} 18$ & $\mathrm{C} 13$ & $\mathrm{C} 14$ \\
\hline Window-West & C18 & $\mathrm{C} 12$ & $\mathrm{C} 18$ & $\mathrm{C} 18$ & C13 & $\mathrm{C} 14$ \\
\hline WindowShading-South & D9 & D8 & D2 & D3 & D8 & D8 \\
\hline WindowShading-North & D9 & D8 & D7 & D9 & D8 & D8 \\
\hline WindowShading-East & D9 & D8 & D8 & D9 & D8 & D7 \\
\hline WindowShading-West & D9 & D8 & D8 & D6 & D8 & D8 \\
\hline RoofInsulation & B7 & B7 & B7 & B7 & B7 & B7 \\
\hline FloorInsulation & $\mathrm{H} 10$ & $\mathrm{H} 2$ & $\mathrm{H} 1$ & $\mathrm{H} 7$ & $\mathrm{H} 1$ & $\mathrm{H} 1$ \\
\hline WallInsulation-North & G8 & E1 & G3 & F7 & $\mathrm{F} 1$ & $\mathrm{~F} 1$ \\
\hline WallInsulation-South & F9 & E5 & G8 & $\mathrm{F} 4$ & E6 & $\mathrm{F} 4$ \\
\hline WallInsulation-East & G8 & G8 & F8 & G8 & G8 & F7 \\
\hline WallInsulation-West & G8 & G7 & G6 & E1 & F7 & F8 \\
\hline \multicolumn{7}{|l|}{ Results } \\
\hline Heating Energy Saving (\%) & 61.36 & 39.24 & 48.71 & 57.44 & 34.90 & 41.31 \\
\hline Cooling Energy Saving (\%) & -77.94 & 10.61 & 4.38 & -46.33 & 20.18 & 18.62 \\
\hline $\mathrm{NPV}(\mathrm{TL})$ & -72424.4 & 54905.93 & 57670.55 & -24147.3 & 67247.25 & 74914.67 \\
\hline
\end{tabular}

*For more information about ID of alternative materials please see Table 3, 4, 5.

Izmir. Meanwhile, the rock wool insulation materials with the IDs of E1 and E5 were assigned to north and south exterior walls, and the materials with the IDs of G8 and G7 were assigned to east and west walls respectively. Lastly, as part of the result at the maximum NPV point in Optimization I (Table 6), the set of alternative solutions is suitable to obtain savings in both heating and cooling consumptions. The alternative window with the ID of C18 (see Table 4) with the lowest $U$ value, high SHGC and the highest unit cost were assigned to east and west windows that have less window area than the windows on south and north directions. However, the window alternatives with the ID of C13 and C16 were selected for the south and north directions. While the alternative shading with the ID of D2 (see Table 5) having almost the lowest depth value was assigned to south window, the shading alternatives with almost the highest depths (ID of D7 and D8) were selected to windows in other directions. The alternative insulation material with the highest thickness (with the ID of B7) was assigned to roof, and the insulation material with lowest thickness was assigned to ground floor.

If we look at the assigned set of energy saving solutions of Optimization II (for maximum cooling energy saving) in Table 6, we first have to focus on the maximum cooling saving point due to the main aim of the optimization. The alternative window "tinted low-e double glazingair filled" with the ID of C13 (see Table 4) having the lowest SHGC value $(0.44)$ and low $U$ value $\left(1.6 \mathrm{~W} / \mathrm{m}^{2} \mathrm{~K}\right)$ was assigned windows in south, east and west directions, while the alternative window with the ID C3 was selected for north direction. When taking into account the negative impact of SHGC on the cooling energy savings, this selection can be remarked as rational. Parallelly, the shading with the highest depth value (ID of D8) (see Table 5) was selected for all windows in each direction. While the glass wool insulation material with the highest thickness (ID of B7) was assigned to roof, the XPS insulation material with the lowest thickness (ID of H1) was assigned to the ground floor in order to obtain maximum cooling energy saving (see Table 3 ). On the exterior walls, while the EPS insulation material with the lowest thickness (ID of F1) was assigned to exterior walls in north direction, the different insulation materials with higher thicknesses were selected for the other walls. It can be argued that the combination of these assigned alternative materials is reasonable for increasing the cool- 
ing energy savings. If we look at the result of maximum heating energy saving point as part of Optimization II (Table 6), although this optimization run was done to obtain maximum cooling energy savings, the maximum heating saving point showed comparable results in terms of saving percentage with the same point in Optimization I. At the maximum heating saving point within Optimization II, the window alternative with the ID of C18 was assigned to all windows as in Optimization I. While the shading elements were not designated to north and east directions, the shading was assigned to south and west directions due to the weight factors chosen. Glass wool insulation material with the highest thickness (ID of B7) was assigned to roof, and the alternative with high thickness (ID of H7) was assigned to ground floor. On the exterior walls, the alternative materials with higher insulation thicknesses (ID of F7 and G8) were assigned to north and east façades, respectively. Finally, in accordance with the result of maximum NPV point as part of Optimization II (Table 6), good enough saving percentages were obtained for both heating and cooling energy savings in addition to the maximum NPV.

Practically the same window alternative (ID of C14) was assigned to all windows except on south side. Shading alternative with the highest depth was assigned to almost all the windows. The selected material for roof and ground floor are the same for maximum cooling saving point. The EPS alternative insulation material with different thicknesses was assigned to exterior walls. As a result of Optimization II, we can propose both maximum cooling energy saving point and maximum NPV point as satisfactory set of solutions due to having more balanced savings among the all objectives and comparable between each other.

Optimal Set of Solutions based on Heating and Cooling Energy Savings for Ankara

The results of Optimization I and Optimization II to obtain maximum heating and cooling energy savings in Ankara are presented in Figures $4 a$ and b separately.

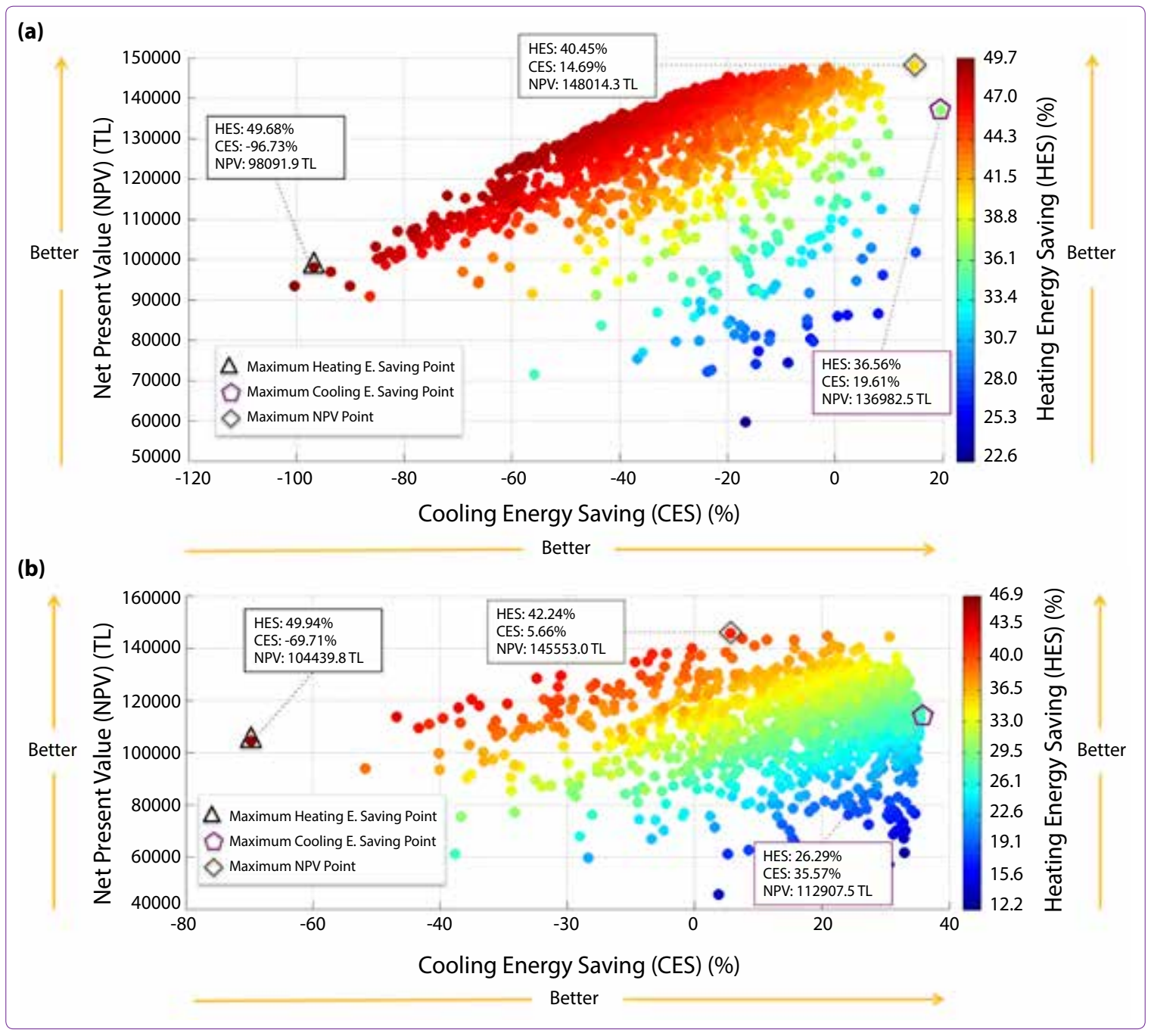

Figure 4. Optimization results for Ankara (a) results for maximum heating energy savings, (b) results for maximum cooling energy savings. 
According to Figure $4 a, b$, the first prominent point is that while the heating energy savings are negatively correlated with cooling energy savings as in the optimization results for Izmir, there is positive relationship between heating energy savings and NPV unlike the Izmir results. This result may arise due to the climatic conditions of two cities and the initial energy consumption values.

On Figure $4 a$, compared to the base-case condition, the maximum heating energy saving is $49.68 \%$ with $96.73 \%$ in cooling energy loss and 98091.9 TL NPV gain at the end of the 10 -year period. The maximum cooling energy saving is $19.61 \%$ corresponding to $36.56 \%$ heating energy saving and 136982.5 TL NPV gain. At the maximum NPV point on Figure 4a, NPV gain is $148014.3 \mathrm{TL}$, the heating energy saving is $40.45 \%$ and the cooling energy saving is $14.69 \%$.

On Figure $4 b$, the maximum cooling energy saving is $35.57 \%$ corresponding to $26.29 \%$ heating energy saving and 112907.5 TL NPV gain at the end of the 10-year period. The maximum heating energy saving is $46.94 \%$ with $69.71 \%$ in cooling energy loss and 104439.8 TL NPV gain. At the maximum NPV point on Figure 4b, 10-year NPV gain is $145553.0 \mathrm{TL}$, the heating energy saving is $42.24 \%$ and the cooling energy saving is $5.66 \%$.
The assigned set of alternative solutions of each data point marked on both Figures $4 a$ and $b$ are presented in Table 7 under the title of "Optimization I (For maximum heating energy saving)" and "Optimization II (For maximum cooling energy saving)" separately.

According to Table 7 and the results of Optimization I (for maximum heating energy savings), at the maximum heating saving point, the window alternative with the ID of C18 triple glazing (see Table 4) having the lowest $U$ value and high SHGC value was assigned to all windows of the building as in the maximum heating energy saving result of Izmir. Similarly, the shading elements were not assigned to any windows (with the ID of D9) except for the windows on the east façade (see Table 5). The alternative insulation material B7 (see Table 3) with the highest thickness was selected for roof insulation, and the alternative material with the ID of $\mathrm{H} 8$ with a high thickness was assigned to ground floor in order to increase the heating energy savings. On the exterior walls, the XPS insulation material with the IDs of G8 and G7 which have the lowest conductivity were assigned to windows on south and north directions.

Additionally, EPS alternative insulation materials with the IDs of F9 and F8 with $140 \mathrm{~mm}$ and $120 \mathrm{~mm}$ thicknesses

Table 7. The results of Optimization I and II for Ankara: The combination of assigned alternative energy saving solutions (with their IDs) of each data point marked on both Figure $4 a-4 b$

\begin{tabular}{|c|c|c|c|c|c|c|}
\hline \multirow{3}{*}{$\begin{array}{l}\text { Ankara } \\
\\
\text { Building Envelope } \\
\text { Components } \\
\text { (Decision Variables) }\end{array}$} & \multicolumn{3}{|c|}{$\begin{array}{c}\text { Optimization I } \\
\text { (For Maximum Heating Energy Saving) }\end{array}$} & \multicolumn{3}{|c|}{$\begin{array}{c}\text { Optimization II } \\
\text { (For Maximum Cooling Energy Saving) }\end{array}$} \\
\hline & \multicolumn{3}{|c|}{ The ID of Alternative Energy Saving Solutions* } & \multicolumn{3}{|c|}{ The ID of Alternative Energy Saving Solutions* } \\
\hline & $\begin{array}{c}\text { Max. } \\
\text { Heating } \\
\text { Saving Point }\end{array}$ & $\begin{array}{c}\text { Max. } \\
\text { Cooling } \\
\text { Saving Point }\end{array}$ & $\begin{array}{l}\text { Max. } \\
\text { NPV Point }\end{array}$ & $\begin{array}{c}\text { Max. } \\
\text { Heating } \\
\text { Saving Point }\end{array}$ & $\begin{array}{c}\text { Max. } \\
\text { Cooling } \\
\text { Saving Point }\end{array}$ & $\begin{array}{l}\text { Max. } \\
\text { NPV Point }\end{array}$ \\
\hline Window-South & C18 & $\mathrm{C} 4$ & $\mathrm{C} 17$ & C18 & $\mathrm{C} 3$ & C18 \\
\hline Window-North & C18 & C18 & $\mathrm{C} 14$ & C18 & $\mathrm{C} 3$ & C18 \\
\hline Window-East & $\mathrm{C} 18$ & $\mathrm{C} 10$ & $\mathrm{C} 10$ & C18 & $\mathrm{C} 13$ & $\mathrm{C} 11$ \\
\hline Window-West & C18 & C15 & $\mathrm{C} 12$ & C18 & C13 & C9 \\
\hline WindowShading-South & D9 & D6 & D8 & D3 & D8 & D8 \\
\hline WindowShading-North & D9 & D8 & D8 & D9 & D8 & D5 \\
\hline WindowShading-East & D6 & D8 & D8 & D9 & D8 & D8 \\
\hline WindowShading-West & D9 & D8 & D8 & D6 & D8 & D8 \\
\hline Rooflnsulation & B7 & B7 & B5 & B7 & B7 & B7 \\
\hline FloorInsulation & $\mathrm{H} 8$ & $\mathrm{H} 1$ & $\mathrm{H} 1$ & $\mathrm{H} 7$ & $\mathrm{H} 1$ & $\mathrm{H} 1$ \\
\hline WallInsulation-North & G8 & G8 & F7 & F7 & G1 & G8 \\
\hline WallInsulation-South & G7 & $\mathrm{F} 4$ & G8 & $\mathrm{F} 4$ & $\mathrm{~F} 1$ & E6 \\
\hline WallInsulation-East & F9 & G8 & F9 & G1 & E6 & G6 \\
\hline WallInsulation-West & F8 & G3 & F7 & E1 & E2 & G8 \\
\hline \multicolumn{7}{|l|}{ Results } \\
\hline Heating Energy Saving (\%) & 49.68 & 36.56 & 40.45 & 46.94 & 26.29 & 42.24 \\
\hline Cooling Energy Saving (\%) & -96.73 & 19.61 & 14.69 & -69.71 & 35.57 & 5.66 \\
\hline $\mathrm{NPV}(\mathrm{TL})$ & 98091.9 & 136982.5 & 148014.3 & 104439.8 & 112907.5 & 145553.0 \\
\hline
\end{tabular}

*For more information about ID of alternative materials please see Table 3, 4, 5. 
were designated to east and west walls. It can be argued that this set of alternative solutions is reasonable to obtain very satisfactory heating energy saving. At the maximum cooling energy saving point within Optimization I (Table 7), while the alternative windows with the IDs of $\mathrm{C} 10$ and $\mathrm{C} 15$ having similar thermal properties were assigned to windows on the east and west directions, the alternative with the ID of C18 was selected for the north windows. Surprisingly, the window alternative with the ID of C4 (see Table 4) that has high $U$ value was assigned to windows on south direction. This result could be due to optimization algorithm stuck in one of the local minima points. The other material assignments are similar to the maximum cooling point results of Izmir. Lastly, at the maximum NPV point in Optimization I (Table 7), the set of alternatives was selected to obtain savings in heating and cooling at the same time. For instance, the alternative windows with low $U$ value and SHGC were usually the selection for windows, and the insulation material with the lowest thickness was assigned to ground floor. As a result of Optimization I, we can propose both maximum cooling energy saving point and maximum NPV point as the satisfactory set of solutions due to having similar total energy savings and NPV.

Looking at the assigned set of energy saving solutions during Optimization II (for maximum cooling energy saving) in Table 7, at the maximum cooling saving point, the only difference in window assignment compared to the maximum cooling result of Izmir is that the alternative window with the ID of C3 "tinted single glazing $4 \mathrm{~mm}$ " having high $\mathrm{U}$ value $\left(5.2 \mathrm{~W} / \mathrm{m}^{2} \mathrm{~K}\right)$ and median SHGC value $(0.54)$ was selected for south direction. This result may arise due to the lower cooling demand of Ankara than Izmir. The shading alternative with the highest depth value (ID of D8) (see Table 5) was selected for all windows similarly to Izmir. The glass wool insulation material with the highest thickness (ID of B7) and the XPS insulation material with the lowest thickness (ID of $\mathrm{H} 1$ ) were selected for roof and ground floor. On the exterior walls, contrary to the results of Izmir, the alternative insulation materials with almost the lowest thicknesses (IDs of G1, F1 and E2) were assigned to all exterior walls except for the east wall. This anomaly could also be due to the optimization algorithm stuck in one of the local minima points. On the maximum heating energy saving point in Optimization II (Table 7), the combination of assigned alternative materials is the same with the result of maximum heating saving point within Optimization II in Izmir except for the alternative insulation material assigned on east wall. Finally, at the maximum NPV point as part of Optimization II (Table 7), while the window alternative with the ID of C18 was assigned to windows in south and north directions, the alternatives with the ID of C11 and $\mathrm{C} 9$ were assigned to east and west direction windows respectively. The shading alternative with almost the high- est depth value was selected for all windows. The alternative insulation materials (IDs of $\mathrm{B} 7$ and $\mathrm{H} 1$ ) with the highest and lowest thicknesses were assigned to the roof and ground floor. The alternative EPS insulation material with different thicknesses were selected to all exterior walls of the building.

\section{Conclusion}

Buildings play a significant role to reduce the total energy use in local and global scale. One of the key steps on improving building energy efficiency is to select the most suitable energy saving solutions among a large number of available alternatives being derived from a large set with different purposes and characteristics. In addition to this, there are generally more than one objective to satisfy simultaneously during the selection of alternative energy saving solutions combination. Therefore, this is a multiobjective optimization problem characterized by the existence of multiple and conflicting objectives with trade-off relationships.

This study presented a simulation based optimization approach based on the integration of EnergyPlus building performance simulation program with GenOpt optimization engine to identify the optimal set of energy saving solutions by searching within a wide decision space including alternative building materials ranging from external wall insulation to different window types per building envelope components (windows, shading materials, external walls, roof, and floor) in order to optimize building heating and cooling energy savings, and NPV objectives simultaneously. The approach was applied to a hypothetical office building to show its applicability, and also to provide decision-support during improvement of building energy performance. Two different optimizations to obtain the maximum heating and cooling energy savings were performed for Izmir and Ankara that represent the different climatic zones in Turkey. This approach allowed concurrent consideration of all available building alternative combination. The optimization results showed apparent trade-off relationships among the objectives. For example, based on the optimization results for Izmir, there were clear tradeoff relationships among objective criteria. In Ankara, while there was negative relationship between heating and cooling energy savings, there was positive relationship between heating energy savings and NPV unlike the results of Izmir. At the maximum heating energy saving point in Izmir, both cooling energy saving and NPV had negative values as there were losses in both of these objectives. On the contrary, at the maximum heating energy saving point in Ankara, all of these three objectives had positive values at the same time. This result possibly arises from the differences between climate characteristics of Izmir and Ankara, and initial parameter values assigned to optimization 
algorithm. Because of the positive relationship between cooling energy saving and NPV, the maximum NPV points on both of two optimization results for Izmir and Ankara were too close the maximum cooling energy saving points while they were far away from the maximum heating energy saving points. Eventually, it can be deduced that the optimization algorithm could accurately find the suitable and satisfactory set of energy saving solutions for both Izmir and Ankara with a cost effective manner. It can also be concluded that the interaction between the conflicting objectives and their trade-off relationships should be analysed in detail while determining the energy efficient building solutions with a cost effective manner.

For the future studies, this approach can be used to evaluate different energy saving strategies (e.g. renewable energy technologies, HVAC systems), with different objective criteria (thermal comfort, $\mathrm{CO} 2$ emission etc.).

\section{References}

Asadi, E., Da Silva, MG., Antunes, CH., Dias, LS., and Glicksman, L. (2014) "Multi-Objective Optimization for Building Retrofit: A Model Using Genetic Algorithm and Artificial Neural Network and An Application", Energy and Buildings, vol. 81, pp. 444-456.

Bayraktar, B. (2015) “A Methodology for Energy Optimization of Buildings Considering Simultaneously Building Envelope HVAC and Renewable System Parameters" Unpublished PhD. Thesis, Istanbul Technical University, Graduate School of Science Engineering and Technology, Istanbul, Turkey.

Chantrelle, FP., Lahmidi, H., Keilholz, W., Mankibi, M. E., and Michel, P. (2011) "Development of A Multicriteria Tool for Optimizing the Renovation of Buildings", Applied Energy, vol. 88, pp. 1386-1394.

Concerted Action EPBD. (2014) "Enegy Performance of Buildings", http://www.epbd-ca.eu/ [Accessed 10 January 2015]

Eberhart, R., and Kennedy, J. (1995) "A New Optimizer Using Particle Swarm Theory", Sixth International Symposium on Micro Machine and Human Science 1995 (MHS ‘95), Nagoya, Japan, pp. 39-43.

European Commission. (2015) "Energy Efficiency in Buildings", https://ec.europa.eu/energy/en/topics/energy-efficiency/ buildings [Accessed 19 December 2015].

European Union. (2010) Directive 2010/31/EU of the European Parliament and of the Council of 19 May 2010 on the Energy Performance of Buildings (recast), Official Journal of the European Union, 53.

Ganiç, N. and Yılmaz, AZ. (2014) "Adaptation of the Cost Optimal
Level Calculation Method of Directive 2010/31/EU Considering the Influence of Turkish National Factors", Applied Energy, vol. 123, pp. 94-107.

Gucyeter, B. and Gunaydin, HM. (2012) "Optimization of An Envelope Retrofit Strategy for An Existing Office Building", Energy and Buildings, vol. 55, pp. 647-59.

Hasan, A., Vuolle, M., and Siren, K. (2008) "Minimisation of Life Cycle Cost of A Detached House Using Combined Simulation and Optimisation", Building and Environment, vol. 43 (12), pp. 2022-2034.

Lin, S. E. and Gerber, DJ. (2014) “Designing-In Performance: A Framework for Evolutionary Energy Performance Feedback In Early Stage Design", Automation in Construction, vol. 38, pp. 59-73.

National Renewable Energy Laboratory (NREL). (2014) “OpenStudio v.1.3.0", https://www.openstudio.net/[Accessed 10 January 2015]

Nguyen, AT., Reiter, S. and Rigo, P. (2014) "A Review on Simulation-Based Optimization Methods Applied to Building Performance Analysis", Applied Energy, vol. 113, pp. 1043-58.

Senel Solmaz, A., Halicioglu, FH. and Gunhan, S. (2016) "A Simulation Based Optimization Approach for Determining the Optimum Energy Saving Solutions for Buildings" Third IBPSA-England Building Simulation \& Optimization Conference 2016, 12-14 September 2016, Newcastle upon Tyne, UK, pp. 274-281.

Senel Solmaz, A. (2015) "A Decision Support Model Based on Simulation and Multi-Objective Optimization to Determine Optimum Solutions for Building Energy Performance" Unpublished PhD. Thesis, Dokuz Eylul University, The Graduate School of Natural and Applied Sciences, Izmir, Turkey.

US Department of Energy. (2014) "EnergyPlus 8.1.", http:// apps1.eere.energy.gov/buildings/energyplus/[Accessed 10 January 2015]

US Department of Energy. (2012) 2011 Buildings Energy Data Book, Silver Spring, Maryland: D\&R International, p.286.

Wetter, M. (2011) "GenOpt - Generic Optimization Program-User Manual version 3.1.0.", Berkeley, CA: U.S. Lawrence Berkeley National Laboratory (LBNL)-Simulation Research Group.

Wright, JA., Loosemore, HA. and Farmani, R. (2002) "Optimization of Building Thermal Design and Control by Multi-criterion Genetic Algorithm" Energy and Buildings, vol. 34, pp. 959-72.

- This paper was formed as an extension of the conference paper entitled "Determining the optimum financial and energy saving solutions for buildings in different climates" that was presented at the $12^{\text {th }}$ International HVAC+R \& SANITARY Technology Symposium organized by the Turkish Society of HVAC \& Sanitary Engineers on March 31 - April 2, 2016 in Istanbul. 